\title{
Arrestin Domain-Containing Protein 3
}

National Cancer Institute

\section{Source}

National Cancer Institute. Arrestin Domain-Containing Protein 3. NCI Thesaurus. Code C117152.

Arrestin domain-containing protein $3(414 \mathrm{aa}, \sim 46 \mathrm{kDa})$ is encoded by the human ARRDC3 gene. This protein plays a role in the regulation of adrenergic receptor signaling pathways. 